\title{
THE ANALYSIS OF LANGUAGE STYLE AND THE ILLOCUTIONARY ACT FOUND IN TEEN LIT NOVEL "THE PERFECT HUSBAND" WRITTEN BY INDAH RIYANA
}

\author{
Nisi Nispi Rahayu ${ }^{1}$, Aseptiana Parmawati \\ ${ }^{1}$ IKIP Siliwangi \\ ${ }^{2}$ IKIP Siliwangi \\ ${ }^{1}$ nisirahayu2015@gmail.com, ${ }^{2}$ aseptianaparmawati@gmail.com
}

\begin{abstract}
In this study described of the Language Style and Illocutionary Act that found in a teen-lit novel "The perfect Husband" Written By Indah Riyana. The methodology that used in this study is Descriptive Qualitative Method. Source of data gained from novel "The Perfect Husband". The steps are: 1). The researchers read the novel, 2). Collecting and analyzing the sentences that consist of language style and the illocutionary act, 3). Draw the conclusion finding based on the data analysis. In this study, the Language Style found are five style but it concern to casual style because that is a teen lit novel, and the illocutionarry act that found are five categories but mostly is used of derective and expressive.
\end{abstract}

Keywords: Language Style, Illocutionary Act, Teen lit novel

\section{INTRODUCTION}

One of the purposes of language study is to communicate, so I can understand others people, then they can to understand me. The effective communication requires knowing how, when, and why to say what to whom by your language. Language style is the part of language varieties aspect of human life. As a human being, language use as a tool of communication. To create an interaction in society, people need to communicate that the way to establish interrelationship and relationship with other people. The language also maintains use as the way to express human feeling, emotions, ideas, then through by using sounds, gestures and also signals that have a pattern. In another word, this can allow people to deliver information or receive information.

The language style in the novel is one of the elements that build a line story. Language styling is referred to language which has been mixed with stylistic elements, especially a figure of speech or language style. According to Keraf (1985: 113) as cited in Anekawati, Nababan, \& Santosa (2020), language style is a process of expressing thoughts using language that typically shows the soul and personality of the writer or language user. It states, that the style of language present of the author's personality with the intention that the reader understand about the contents of the novel. And its refers to language as the way to convey the information related by using differences of expression and variations of language that are used in the different situation and needs surrounding the circumstance.

There are many experts have different opinions about language style, for example on Martin Joos theory, he divides language style into five types there are frozen style, formal, consultative, casual and intimate style (Joos, 1967). On the other hand, language style also the way to show our expression whether formal or in an informal situation. They talk about how people can 
communicate or do conversation by using their own style. People cannot leave language style because it is a fundamental language style.

According to Petriandy \& Marlina (2018), pragmatics is the study that talk about speakers meaning. In other word, pragmatics is study about the meaning of the context between the speaker and the hearer. Meanwhile, with pragmatics, people can talk to other people intended meanings, their assumption, their purposes or goals, and the kinds of action that they are performing when they speaks (Yule, 1996:40). In that case, all those are speech acts include: locutionary, illocutionary, perlocutionary.

Illocutionary act is one of the pragmatic assessments that are usually used in daily conversation or writing, which is means, it depends on the situation and condition when the speaker (or writer) convey to hearer (or reader) and it means of what the speaker (or writer) means that illocutionary act is closely related with the language that we use every day. Furthurmore, according to Selviyani, S., \& Pujiati (2019), in the novel is contains a lot of conversations that can be analyzed of speech act. In addition, illocutionary act is the act to doing something that is talking about the purpose, function, or power of speech that concerned. As well as to convey messages to the reader, if we as the writer. The example can found in novel is it the interaction between writer and reader.

According to Rachmijati \& Anggraeni (2018), teenlit novels are one of the type genres in novels, that began to bloom in Indonesia since the 2000s there was the novel DeaLova which sold 10.000 copies. Teenlit novel itself was actually a contemporary tales that successfully combines the two needs, 1). the needs of the community will mirror themselves and 2). the society needs 'dream world'. Meanwhile, based on Hafizh (2019), teen lit itself has unique characteristics include: protagonists are always teenagers, adult figures are sometimes marginalized, use adolescent language styles or slang, tell the lifestyle and characteristics of adolescents. It means, that teen-lit is one of a popular literature it contains a various story about teenagers and the content that is closely related to adolescent life.

There ones of those special characteristics use of foreign language term, especially in the English language. As example in The Perfect Husband novel "Intinya, Ay malam ini ingin refreshing otak dulu sama teman-teman". Another example "See you soon Baby. Mwahh!", "You know, saat ini aku masih mengabdi menjadi mahasiswi abadi disalah satu universitas swasta tempatku menuntut ilmu". The contradiction it arises due to assume, that the style of language used in teen-lit not only use the Indonesian language, the content is also considered too light and weightless, and the lifestyles that tend to lead to the cultures of westerns lifestyle.

In this era, people can to read kinds genre of the novel not only by book form but there is a digital media platform such as Wattpad for the reader that wants to read all of the genres in novels. The example of famous novels was in Wattpad and has been filmed is Dear Nathan by Erisca Febriani. In this research, the writer will discuss one of the teen-lit novels and try to analysis about the language style and the illocutionary act in the novels, which is titled "The Perfect Husband" Written by Indah Riyana. This novels tells about an immoral students girls who is struggling with her thesis, where are many problems that arise in the story. Researchers is interested in conducting research used it as object because there are contain a lot of expressive utterances and language style. 


\section{METHOD}

In this research used descriptive qualitative method. This research design to analyze the data and make a description about the types of language style, then to find out what kinds of illocutionary act also to define the functional meaning of utterances produced by the main characters in the novel. By applying this research method, the researcher would to describe and interpret the current problem based on the data. This research deal with the sentences and the conversation from a novel The Perfect Husband as a data and a source.

In addition, based on Perry (2005) as cited in Rahayu, A. S., Syahrizal, T., \& Sadikin, (2019), qualitative research is characterized by the verbal description of its data. It enables the researcher to represent of the result as a complex situation reflected in the society. In this case, the reason of researchers used qualitative approach because the writer did not pay attention on the numbers of occurrence. It tends to explain the various forms for utterances to express the concept. Based on the technique of descriptive qualitative the data analyzing steps are as follows: (1) reading repeatedly texts of the Perfect Husband. (2) to classifying the words is by writing down sentences into several categories which contain the use of language style such as formal style, informal style, casual style, consultative style and also the illocationary act such as declaration, representative, expressive, directive, and commissive. In the last step, the researcher draw the conclusion based on the analysis findings of the research.

\section{RESULTS AND DISCUSSION}

\section{Results}

In this addition, is conduct of research findings. Based on the analysis of the conversation from the novel The Perfect Husband, there are the conversation which belong to the types of a language style and illocutionarry act according to Martin Joos in The Five Clocks:

\section{a. Types of Language Style}

According to Martin Joos in The Five Clocks the types of language style are :

1. Frozen Style is the style of language that is used of social strangers

There are conversation that indicate to frozen style. one of the example can be seen in :
a). A : Maaf, mau cari siapa? (p.10)
B : Tunggu sebentar, kedatangan saya kesini ingin bertemu dengan keluarganya om Tio
b). Begini saja Tuan Arsen yang Terhormat (p.48)
c). A : Ngapain kamu berdiri disitu? (p.267)
B : "Sa-saya Cuma mau antar pesanan Anda" waiters said.

2. Formal Style is the style that generally used in addressing a large of audience There are conversation that indicate to formal style. one of the example can be seen in :

a). Om, Tante maksud kedatangan saya beserta rombongan kesini bermaksud melamar anak Om dan Tante secara resmi. (p.101)

b). Bu, Pak, sudah waktunya jenazah dimandikan" said Arsen (p.404)

3. Consultative Style is the style used generally of bussiness talks and small group discussion, does involve participantion by addressee

There are sentence and conversation that indicate to consultative style. one of the example can be seen in : 
a). A : Ayla berhubung kita belum buat sambutan untuk kamu,gimana pulang kerja saya traktir karaokean? (Boss) (p.374)

B : Pak, kita-kita juga dong.

b). A : "Selamat bu usia janin diperkirakan delapan minggu" doctor. (p.433)

B : Tapi, Dok, selama ini saya minum pil KB

c). "Untuk itu saya ingin meminta maaf yang sebesar-besarnya karena saya sudah tidak professional dalam bekerja, Pak”Ayla said to her Boss (p.442)

4. Casual / Informal Style is the style used in which friends and "insders" speak.

There are word, sentence or conversation that indicate to casual or informal style. one of the example can be seen in :

a). Yap! (p.11)

b). Idih! (p.28)

c). A : Ha? Yang bener? (p.153)

$B: H m$.

d). A : Satu lagi, stop ejek istri gue kuntilanak (p.279)

B : Terus apa dong kalo bukan kuntilanak? Nenek lampir, ibu tiri, atau Maleficent?

e). A : Kamu apa kabar? Habis dari mana nih?(p.366)

$B$ : Alhamdulillah, baik.

5. Intimate Style which is the style characteristic by the use of the private and relatively permanent language code of the group and by extraction (DeVito, 1990:18)

There are sentence or conversation that indicate to intimate style. One of the example can be seen in :

a). See you soon, baby (p.17)

b). Ayla sayang, ayo sini gabung sama kita (p.26)

c). A : Maaf aku telat, baby (p.88)

B : It's okey baby

d). A : Aku nggak lapar (p.172)

B : Sarapan dulu, Sayang, nanti sakit

e). A : "Laper, Yang....” (p.329)

B : Kaти kan baru makan satu jam yang lalu Arsen. Masa laper lagi sih?

b. Types of illucationary Act

According to Hutajulu, L. S. F ., \& H (2019), illocutionary Acts is part of speech act, it's the basic act of utterance, or producing a meaningful linguistic expression. In other word, language itself is part of a theory of action and speech acts are those verbal actions like promising, threatening, and requesting that one performs in speaking based on Searle (1969:24) in (Selviyani, S., \& Pujiati 2019). Further the "Illocutionary acts is occurs when the speaker utters a sentence, means what she says, but also means something more". According to John Searle's Taxonomy of Elementary Illocutionary Act,, there are five types of illocutionary acts such as :

1. Declarations, is the influence change the world via an utterance, depend to the speakaaer has a roles in the context

a). Ya sudah, kita langsung aja tentukan tanggal pernikahan untuk Arsen dan Ayla.

"The utterence is change the world because the speaker have in a role as a father" (p.3031)

b). Aku mau menikah sama kamu. (p.129) "When the speaker said that, the utterance means can be change her hearer world". 
c). Saya ingin mengenal Ayla lebih jauh lagi, Om. (p.276) "When the speaker said that, the utterance means to change the speaker world".

2. Representative, is usually used to state what the speaker believes to be the case or not. Also it can to telling about the fact that only speaker know

a). Sebenarnya, Papa kamu yang suruh saya untuk mengikuti kemana kamu pergi. (p.44) "The utterance is showing that the speaker telling the truth if he only follow instruction from her father"

b). Dulu waktu Mas kamu melamar Mbak Dita, Mbak juga takut dan cemas seperti kamu. (p.95). " The speaker telling the fact about the phenomena in her life so the utterance means to give an information about speaker believe".

c). Sudahlah Bu, ini cuma kecelakaan (p.215). "The speaker telling the fact about the phenomena, so the utterance means to give an information about speaker believe and to hang on the hearer".

3. Commissives, the utterence is focused on committing the speaker to some future course of action

a). Saya juga janji, tidak akan membuat hati kamu patah (p.47). The utterance is showing promising of the speaker to hearer

b). Saya peduli sama perasaan kamu. Bahkan saya berjanji untuk membuat kamu bahagia (p.75)."The The utterance is showing future action and threating with promises to his hearer" c). Saya janji akan menjadi imam yang baik buat kamu (p.130)." The utterance is showing promising of the speaker to hearer"

4. Directives, is the utterance express the speaker's desired and become the reason for the hearer or addressee to act

a). Please, jangan paksa Ayla Pa.(p.35) "That utterance is showing that the speaker is suggest the hearer to act in, it shown by word "jangan paksa"

b). Kamu harus nikahin aku. (p.39) "That utterance is showing that the speaker is suggest the hearer to act in, it shown by the context".

c). Listen to me. (p.50) "That utterance is showing the reason for the hearer to act".

5. Expressives, are those kinds of illocutionary acts that show what the speaker feels such as : like, dislike or disagreement toward someone or something in expressives for attitudes.

a). Ayla ini memang lucu ya. Nenek jadi makin suka deh sama Ayla (p.28)

"The utterance is showing the speaker feeling, it shown by word " makin suka" it refers to her feeling".

b). Jaga ucapanmu, Ayla! (p.34) "That utterence is showing the speaker feeling, it shown in the topic of utterance that speaker feeling angry to his daughter".

c). Ih jelek banget pokoknya. Bahkan lebih jelek lagi dari monster di film Beauty and the Beast. (p.64) "That utterance is showning dislike feeling of the speaker, it shown by the context of utterance".

\section{CONCLUSION}

In conclusion, based on findings and discussions in previous chapter it can be concluded that there are five types of language style. The researcher found it in The Perfect Husband novel they are consist of: frozen style, formal style, consultative style, casual style, and intimate style. The conversation which contains the type of language style that focused on casual and intimate 
style of the conversation from The Perfect Husband novel, because the conversation is mostly in relax situations. In case, it's kind of teen-lit novel that focused on teenager's life.

The types of illocutionary acts were found in a novel the Perfect Husband by Indah Riyana is proposed by John Searle (1979) as cited in (Selviyani, S., \& Pujiati 2019), there such as representatives, commissive, directives, declarations and expressive illocutionary acts. Further, in the daily life the communicating especially based on the conversation obtained from the novel, the participants in the novel used different ways to convey their message. Meanwhile, some of them used direct or indirectly form, they prefer to speak by means of something else.

In this case, the researchers suggests the reader to do the research about the types of language style and illocutionary act for the further discussions. In sense, because there are many interesting aspects which can be analyzed. How important and crucial to learn the types of language style is, whether language style in daily activity, in movies, in magazines, in novel and songs, there is that some people do not know. Therefore means, by learning the types of language and the illocutionary act it can create communicative conversations.

\section{ACKNOWLEDGMENTS}

Alhamdulillah all praise to Allah SWT always blessing me everytime of my life until I able to accomplish this paper. The researcher would like to express her deep gratitude to:

1. My parents, all my familys and friends, who always support and praying for me.

2. Especially, I would like to thanks to my lecturer Mrs. Aseptiana Parmawati M.Pd for her invaluble guidance, suggestion and feedback during this journal project.

3. Also I like to thank all of the journal authors who have been sharing the knowledge about the phrases materials.

\section{REFERENCES}

Anekawati, F., Nababan, M. R., \& Santosa, R. (2020). International Journal Of Linguistics , Literature And Translation ( Ijllt ) Translation Technique Analysis Of Language Style Of Nic , S Character In Beautiful Boy By David Sheff, (2011), 11-17. Https://Doi.Org/10.32996/Ijllt.2020.3.1.2

Hafizh, M. Al. (2019). The Use Of Speech Acts In Indonesian Teenlit: A T Eenager' S Restlessness About The Issue Of Unity And Diversity, 338(Prasasti), 367-372.

Hutajulu, L. S. F ., \& H. (2019). Analysis Of Illocutionary Act In The Movie "You Are My Home" English Subtitle. Journal Of English Educational Study, 2(1), 29-36.

Indah, R. (2016). The Perfect Husband. Jakarta: Romancious.

Joos, M. (1967). The Five Clocks (Vol. 58). New York: Harcourt, Brace \& World.

Petriandy, D. V., \& Marlina, L. (2018). E-Journal Of English Language \& Literature Illocutionary Acts Found In Novel The Never Girls : Before The Bell By Kiki Thorpe. EJournal Of English Language And Literature, 7(1).

Rachmijati, C., \& Anggraeni, A. (2018). The Context Of Languages And Pedagogical Aspects In Teen Lit Novels. Journal Of Language And Literature, 18(1985).

Rahayu, A. S., Syahrizal, T., \& Sadikin, I. S. (2019). Speech Act Analysis Of "Frozen " The Movie Script. Project (Professional Journal Of English Education), 2(5), 692-699.

Selviyani, S., \& Pujiati, T. (2019). Expressive Speech Act In The Novel Dialogue The Perfect Husband, 4778, 343-353.

Yule, George. (2000). Pragmatics. Oxford: Oxford University Press. 